\title{
Mitigasi Bencana (Covid 19) Melalui Kegiatan Multiliterasi Di Sekolah Dasar
}

\section{Disaster Mitigation (Covid 19) through Multiliteration Activities in Elementary Schools}

\author{
Dian Permana Putri ${ }^{1}$, Aisyah ${ }^{2}$ \\ ${ }^{\text {I}}$ Program Studi Pendidikan Matematika, Fakultas Keguruan dan Ilmu Pendidikan, Universitas Swadaya \\ Gunung Jati, Indonesia \\ ${ }^{2}$ Program Studi Bahasa Inggris, Fakultas Keguruan dan Ilmu Pendidikan, Universitas Swadaya Gunung \\ Jati, Indonesia \\ e-mail:1'dpermanaputri@gmail.com,'aisyah.pbi@gmail.com
}

\begin{abstract}
Abstrak
Kegiatan pengabdian kepada masyarakat yang dilaksanakan pada tanggal 29 Agustus 2020 di SDN 2 Kedungdawa Kabupaten Cirebon bertujuan untuk meningkatkan pengetahuan, pemahaman, pengalaman dan kepedulian peserta didik untuk tanggap pada mitigasi bencana khususnya covid 19 melalui kegiatan multiliterasi. Metode pelaksanaan kegiatan adalah penyuluhan/ sosialisasi terhadap definisi bencana, jenis bencana dan cara menanggulangi dan menghadapi bencana covid 19. Hasil kegiatan yang dilaksanakan menunjukkan 24 siswa yang terlibat antusias mengamati video tentang mitigasi bencana yang diputar, serta berpartisipasi aktif dalam tanya jawab. Sebagian besar siswa (95\%) siswa mampu menangkap pesan pada media digital yang diberikan dibuktikan dengan siswa mampu memahami definisi bencana, jenis bencana dan cara mengantisipasi diri dan lingkungan terhadap bencana non alam covid 19. Sehingga dapat disimpulkan bahwa kegiatan penyuluhan yang dilaksanakan berlangsung dengan sukses dan lancar.
\end{abstract}

Kata kunci-mitigasi bencana, covid 19, sekolah dasar, multiliterasi

\begin{abstract}
Community service activities carried out on August 29, 2020 at SDN 2 Kedungdawa Cirebon Regency aim to increase the knowledge, understanding, experience and concern of students to respond to disaster mitigation, especially Covid 19 through multiliteration activities. The method of implementing activities is counseling / socialization of the definition of a disaster, types of disasters and ways of coping with and dealing with covid disasters 19. The results of the activities carried out showed that the 24 students who were involved enthusiastically watched the video about disaster mitigation that was played and actively participated in the question and answer. Most of the students (95\%) were able to capture messages on digital media provided as evidenced by the fact that students were able to understand the definition of a disaster, types of disasters and how to anticipate themselves and the environment against non-natural disasters covid 19. So it can be concluded that the extension activities carried out were successful and smooth
\end{abstract}

Keyword - disaster mitigation, covid 19, elementary school, multiliteration

\section{PENDAHULUAN}

Indonesia merupakan negara beresiko tinggi terjadinya bencana. Secara geologis terletak pada pertemuan Lempeng Eurasia, Indo-Australia dan Lempeng Pasifik. Secara geografis, Indonesia merupakan negara kepulauan dengan bentuk topografi yang bervariasi. Masyarakat merupakan elemen yang memiliki pengalaman langsung dalam kejadian bencana sehingga pemahaman yang dimiliki menjadi modal bagi pengurangan resiko bencana (Zein, 2010). Dalam konteks manajemen bencana alam, respon masyarakat terhadap bencana sangat penting untuk dipahami. respon merupakan awal dari sebuah strategi adaptasi oleh masyarakat yang dihasilkan melalui pemahaman terhadap bencana alam yang terjadi. Pemahaman masyarakat berupa pengetahuan persepsi yang teraktualisasi dalam sikap dan tindakan dalam menghadapi bencana. Hasil dari 
sikap dan atau tindakan masyarakat dalam menghadapi bencana adalah strategi adaptasi yang berarti penyesuaian yang dilakukan akibat dari ancaman lingkungan (Hardoyo, 2011).

Bencana adalah fenomena alam yang tidak dapat diperkirakan datangnya oleh manusia walaupun dengan segala akal dan pengetahuannya, sehingga upaya untuk mengurangi resiko dampak bencana harus melibatkan seluruh elemen masyarakat yang secara tidak langsung terkena dampak bencana melalui aktivitas mitigasi bencana. Mitigasi bencana merupakan suatu aktivitas yang berperan sebagai tindakan dari pengurangan dampak bencana, atau usaha yang dilakukan untuk mengurangi korban ketika bencana terjadi, baik korban jiwa maupun harta benda. Mitigasi bencana mencakup, baik perencanaan dan pelaksanaan tindakan-tindakan untuk mengurangi resiko-resiko yang terkait dengan bahaya-bahaya karena ulah manusia dan bahaya alam yang sudah diketahui, dan proses perencanaan untuk respon yang efektif terhadap bencana-bencana yang benar-benar terjadi

Pendidikan merupakan salah satu sarana yang dapat digunakan untuk mitigasi bencana, dengan memasukkan materi mengenai kebencanaan maka secara tidak langsung siswa belajar untuk mengetahui, memahami, sekaligus belajar mengurangi kerugian akibat bencana yang terjadi sejak usia dini terutama di sekolah-sekolah yang memiliki lokasi rawan bencana. Melalui kegiatan literasi yang telah dicanangkan Pemerintah sejak tahun 2015 yakni, Gerakan Literasi Sekolah (GLS) siswa tidak hanya mendapatkan beragam informasi dan pengetahuan namun juga siswa belajar memahami dirinya sendiri dan lingkungan di sekitarnya. Hal ini dianggap penting bukan hanya untuk merespon data dan fakta hasil survey yang menunjukkan rendahnya minat dan budaya baca masyarakat kita, merujuk pada hasil studi PISA (Program for International Students Assessment) selama 18 tahun, peringkat Indonesia belum pernah naik secara signifikans (OECD, 2019). Lebih penting itu adalah untuk mempersiapkan anak didik kita menghadapi, tuntutan keterampilan membaca abad ke 21 untuk kemampuan memahami informasi secara analitis, kritis dan kreatif.

Multiliterasi merupakan keterampilan membaca, menulis, berbicara, menyimak dan menggunakan teknologi dan informasi dengan tujuan memperoleh beragam pengetahuan, keterampilan mengungkapkan gagasan dan ide yang diolah secara kritis dan kreatif serta dapat dipertanggungjawabkan (Abidin, 2015). Dengan berliterasi membantu peserta didik untuk dapat memecahkan masalah dengan menggunakan keterampilan tingkat tinggi. Kegiatan literasi membantu siswa mempelajari tentang dirinya sendiri serta mengeksplorasi dan mempengaruhi dunia.

Anak-anak perlu dilibatkan dalam pemahaman mitigasi bencana, karena Menurut PP no 21 (2008) anak merupakan salah satu kelompok yang paling rentan terhadap dampak bencana. Kerentanan anak terhadap bencana dipengaruhi oleh faktor keterbatasan dalam memahami resiko di sekeliling mereka sehingga kurangnya kesiapsiagaan dalam menghadapi bencana. Menurut Sunarto (2012) Beberapa data kejadian bencana melibatkan anak-anak sebagai korban bencana baik pada jam sekolah maupun di luar jam sekolah. Fenomena ini menunjukkan pentingnya pengetahuan mengenai bencana dan mitigasi bencana sejak dini sehingga pemahaman dan langkah-langkah yang harus dilakukan saat terjadi ancaman dapat mengurangi resiko bencana. Selama ini pendidikan kebencanaan di SDN 2 Kedungdawa belum disisipkan pada saat pembelajaran dengan optimal. Siswa hanya belajar mengenali jenis bencana alam, belum mempelajari mitigasi bencana melalui kegiatan multiliterasi. Menurut Adiyoso dan Kanegae (2013), edukasi kebencanaan tidak hanya melalui metode ceramah, namun siswa harus terlibat secara aktif pada kegiatan tersebut, seperti simulasi dalam menghadapi bencana, sehingga langkah-langkah antisipasi terhadap ancaman bencana dapat mudah dipahami oleh siswa. Dan munculnya rasa empati terhadap masyarakat yang terkena dampak bencana.

Baru-baru ini seluruh dunia menghadapi pandemic bersama yakni ditemukannya virus flu jenis baru, yakni novel corona virus 19 atau dikenal dengan covid 19. Jenis virus flu ini tingkat kematiannya lebih rendah disbanding H5N1 namun berbeda dengan jenis corona virus lainnya karena gejala baru dialami penderita setelah 14 hari terinkubasi di dalam tubuh, sehingga virus ini dianggap lebih berbahaya karena penyebarannya cepat dan luas. Indonesia merupakan negara dengan jumlah pasien terbanyak ketiga di Asia serta menjadi peringkat pertama angka 
kematian terbanyak di Asia Tenggara, lebih lanjut Kabupaten Cirebon merupakan wilayah lima besar terbanyak penderita covid 19 dan termasuk zona merah di wilayah Provinsi Jawa Barat oleh sebab itu mtigasi/penanggulangan bencana non alam yang terjadi karena wabah penyakit, yakni covid 19 perlu disosialisasikan kepada masyarakat terutama kepada siswa Sekolah Dasar, agar pengetahuan, pemahaman, kewaspadaan terhadap diri dan orang disekitarnya serta rasa empati terhadap korban dapat ditingkatkan.

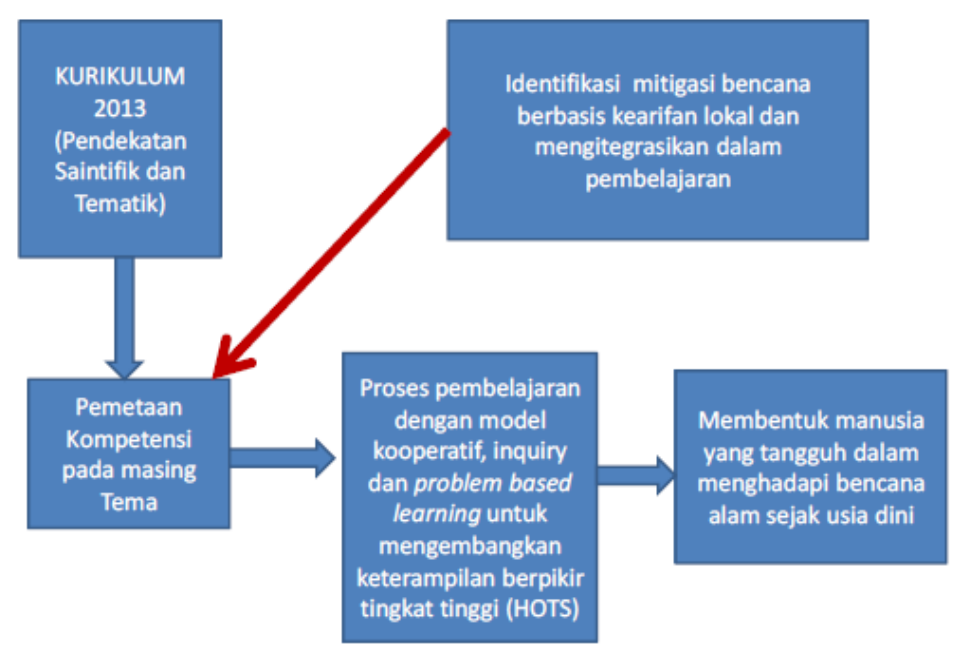

Gambar 1. Model pembelajaran pendidikan kebencanaan (Suarmika \&Utama, 2017)

Hasil wawancara dengan Kepala Sekolah dan guru kelas VI SDN 2 Kedungdawa menyatakan bahwa permasalahan yang terjadi dalam pembelajaran yang dilakukan selama ini, guru hanya memberikan materi mitigasi melalui cerita bergambar atau melalui tayangan video, tanpa melibatkan secara langsung siswa untuk memahami proses terjadinya bencana dan cara mengatasinya. Oleh karena itu, perlunya kegiatan mitigasi bencana diterapkan di didukung dengan media yang tepat sesuai kebutuhan dan karakteristik siswa.

Berdasarkan hasil wawancara dengan kepala sekolah dan beberapa guru serta pengamatan dalam proses pembelajaran, terdapat beberapa permasalahan yang didapat diantaranya :

1. Pemanfaatan media pembelajaran masih kurang maksimal. Pendidik belum membuat alat peraga yang membantu peserta didik memahami proses terjadinya bencana dan mitigasi bencana.

2. Pembelajaran belum didukung dengan media yang tepat, sesuai kebutuhan dan karakteristik peserta didik.

3. Peserta didik belum tanggap situasi dan kondisi dalam menghadapi bencana.

Dalam kegiatan pengabdian ini khalayak sasaran adalah siswa kelas VI sekolah dasar yang berjumlah 24 orang yang belum mengetahui dengan baik mitigasi bencana covid 19 . Sehingga solusi yang ditawarkan untuk permasalahan yang dihadapi mitra adalah : Pembuatan media pembelajaran berbantuan powtoon, pendampingan pembelajaran daring berbantuan video yang sesuai dengan karakter peserta didik, penyuluhan kepada peserta didik, diawali dengan penjelasan definisi bencana, macam bencana dan mitigasi bencana covid 19 secara daring berbantuan video powtoon.

Menurut Undang-Undang Republik Indonesia Nomor 24 tahun 2007 Tentang Penanggulangan bencana, Bencana adalah peristiwa atau rangkaian peristiwa yang mengancam dan mengganggu kehidupan dan penghidupan masyarakat, yang disebabkan oleh faktor alam dan atau faktor non alam, maupun faktor manusia, sehingga mengakibatkan timbulnya korban jiwa manusia, kerusakan lingkungan, kerugian harta benda dan dampak psikologis. Hal ini 
menunjukkan bahwa resiko dampak bencana bergantung pada kerentanan setiap komponen yang terkena dampak.

Menurut Hyogo Framework for Action Tahun 2005, prioritas pengurangan mitigasi bencana perlu diimplementasikan pada ranah pendidikan. Implikasi bencana juga mengakibatkan kerugian pada elemen sekolah seperti guru dan siswa, proses pembelajaran serta properti. Sehingga pendidikan kebencanaan dan mitigasi bencana di sector pendidikan diharapkan dapat mewujudkan generasi dan sekolah Tangguh bencana dan memiliki kesiapsiagaan yang baik tentang bencana (Lesmana dan Purobrini, 2015).

Pendidikan kebencanaan di sekolah harus dimulai sejak usia dini, mitigasi bencana dapat membantu siswa berperan penting dalam penyelamatan hidup dan perlindungan anggota masyarakat (Honesti\&Djali, 2012). Hal ini didukung oleh fakta bahwa setiap tahun diperkirakan sekitar 66 juta anak di seluruh dunia terkena dampak bencana (Herdwiyanti\&Sudaryono, 2013). Dengan meningkatnya pemahaman pengetahuan dan kesadaran siswa terhadap bencana maka kesiapsiagaan siswa meningkat sehingga dapat menguangi resiko terjadinya bencana. Edukasi dengan strategi komunikasi selaras dengan yang telah dilakukan oleh BNPB dengan cara pemberian materi mengenai definisi bencan, dampak yang ditimbulkan bencana hingga upaya mitigasi bencana. Anak-anak mempunyai kerentanan yang tinggi terhadap bencana, sehingga edukasi kebencanaan sekaligus Langkah mitigasi bencana perlu diberikan sejak dini.

Bencana yang sudah menetap di Indonesia hampir satu tahun belakangan ini yaitu wabah penyakit Covid-19. Coronavirus Covid-19 merupakan bencana akibat faktor biologis yang awal mula nya terjadi di negara tirai bambu. Aturan pemerintah dalam menyikapi wabah adalah melalukan social distancing yang berlaku bagi seluruh masyarakat Indonesia. Dampak dalam bidang pendidikan yaitu pembelajaran dilaksanakan dengan menggunakan sistem pembelajaran jarak jauh (PJJ). Dengan melakukan pembelajaran daring diharapkan dapat mengurangi mata rantai terjangkitnya virus (Setyorini, 2020). Pada penelitian ini peneliti akan mengkaji dan menganalisis bencana alam hidrometeorologi banjir dan bencana alam akibat faktor biologi yaitu wabah penyakit covid-19. Dengan adanya pendidikan mitigasi di sekolah dasar meminimalisir kerugian yang disebabkan oleh bencana banjir dan covid-19.

Pemerintah melalui Permendikbud RI no 23 tahun 2015 memfokuskan pada pendidikan budi pekerti salah satunya adalah kebiasaan membaca nonbuku pelajaran selama 15 menit setiap hari sebelum pembelajaran dimulai. Hal ini dianggap penting bukan hanya untuk merespon data dan fakta hasil survey yang menunjukkan rendahnya minat dan budaya baca masyarakat kita, merujuk pada hasil studi PISA (Program for International Students Assessment) tahun 2015 yang menunjukkan Indonesia baru bisa menduduki peringkat 69 dari 76 negara. Lebih penting itu adalah untuk mempersiapkan anak didik kita menghadapi, tuntutan keterampilan membaca abad ke 21 untuk kemampuan memahami informasi secara analitis, kritis dan kreatif.

Multiliterasi merupakan keterampilan membaca, menulis, berbicara, menyimak dan menggunakan teknologi informasi dan komunikasi. Menurut Abadi (2015) literasi dalam konteks multiliterasi adalah keterampilan untuk memperoleh beragam pengetahuan yang diolah secara kritis dan mendalam sehingga menjadi pengetahuan yang mendalam, kemampuan mengungkapkan gagasan dan ide serta dapat mempertanggungjawabkannya. Adapun tujuan dari multiliterasi adalah :

1. Menerapkan kemampuan literasi dalam berbagai konteks keilmuan.

2. Mampu merumuskan ide kreatif, memcahkan maslah, menggunakan keterampilan berpikir tingkat tinggi, melakukan intepretasi secara mendalam dan cerdas.

3. Menanamkan apresiasi tentang nilai dan kekuatan litereasi sehingga akan senantiasa termotivasi untuk berliterasi sepanjang hidup. Berliterasi membantu siswa mempelajari dirinya sendiri, memecahkan masalah, mengeksplorasi dan mempengaruhi dunia.

4. Mengembangkan kemandirian siswa sebagi seorang pembelajar yang kreatif, inovatif, produktif sekaligus berkarakter.

Salah satu cara untuk mengatasi hambatan belajar literasi adalah dengan cara multiliterasi dan multimodal (Cumming-Potvin, 2015). Internet dan jenis teks yang berkembang pesat 
berdampak besar terhadap cara guru dan siswa berliterasi. Kemampuan literasi berkembang melalui aktivitas sosial sehari-hari yang berlangsung di rumah, sekolah maupun komunitas. Pemerolehan literasi dan keterampilan kognitif dapat tercapai melalui keterlibatan dan praktik literasi menggunakan teknologi dan budaya (Cumming-Potvin\&Currie, 2013). Hal ini diperkuat oleh pendapat Pyo (2016) yang menyatakan bahwa siswa lebih tertarik dengan kegiatan literasi yang berorientasi digital dan dimotivasi oleh tujuan sosial dan keinginan bersenang-senang daripada belajar. Multiliterasi pada tahun 2020 menggabungkan komunikasi, pemahaman, analisis kritis, dan keterampilan untuk memahami teknologi digital, video (gambar visual), televisi (gambar digital), dan media baru (layar) pada kegiatan sehari-hari (Ryan, 2020).

Adapun harapan dalam kegiatan ini adalah adanya peningkatan pemahaman, pengetahuan dan antisipasi diri dan lingkungan terhadap penanggulangan bencana dan kesiapan menghadapi bencana pada siswa sekolah dasar.

\section{METODE PELAKSANAAN}

\section{Sasaran Pengabdian}

Pada kegiatan PKM ini sasaran program adalah siswa kelas VI Sekolah Dasar SDN 2 Kedungdawa yang berjumlah 24 orang. Kelas VI dipilih karena telah mempelajari materi bencana pada kelas V. Namun kegiatan pembelajaran dengan materi bencana selama ini belum berjalan maksimal karena media yang digunakan hanya melalui buku teks, dan siswa belum terlibat secara langsung terhadap jenis bencana yang telah dipelajari. Siswa akan diberikan materi bencana covid 19 melalui video pembelajaran berbantuan powtoon, kemudian kegiatan PKM akan dievaluasi melalui respon siswa setelah belajar mitigasi bencana covid 19

\section{Tahapan Pelaksanaan}

Metode pendekatan yang digunakan untuk mengatasi permasalahan yang dihadapi mitra adalah dengan metode pendampingan pembelajaran dan penyuluhan mengenai mitigasi bencana. Secara rinci kegiatan PKM dijelaskan sebagai berikut.

1. Diskusi antara tim PKM dengan mitra untuk memperoleh gambaran permasalahan yang dihadapi mitra, serta penentuan masalah prioritas yang akan dipecahkan dalam kegiatan PKM.

2. Koordinasi antara tim PKM dan untuk menentukan waktu pelaksanaan kegiatan, materi pelatihan dan jadwal kegiatan serta melakukan persiapan pelaksanaan kegiatan seperti pembelian alat dan bahan, pernyiapan lokasi kegiatan.

3. Pelaksanaan kegiatan. pada tahap ini dilakukan :

a. Pendampingan dalam pembelajaran multiliterasi berbasis daring,

b. Penyuluhan mitigasi bencana covid 19 kepada peserta didik melalui video

4. Partisipasi mitra dalam pelaksanaan kegiatan meliputi :

a. Peserta didik mengikuti jadwal kegiatan yang telah disusun

b. Peserta didik mengamati video mitigasi bencana,

c. Peserta didik memahami isi pesan pada video mitigasi bencana, tanggap dan sigap menghadapi/mengantisipasi bencana dan peduli terhadap korban bencana

5. Evaluasi.

Pada tahapan ini dilakukan :

a. Membandingkan kompetensi mitra sebelum dan sesudah pelaksanaan kegiatan penyuluhan

b. Membandingkan tingkat pengetahuan, kemampuan dan kepedulian mitra terhadap mitigasi bencana.

Kegiatan PKM berlangsung satu hari pada tanggal 29 Agustus 2020 yang melibatkan 24 orang siswa dan guru kelas di SDN 2 Kedungdawa Kabupaten Cirebon. Hasil kegiatan untuk membandingkan kompetensi mitra sebelum dan sesudah pelaksanaan kegiatan adalah dengan angket respon terhadap video pembelajaran. Hasil angket respon siswa menunjukkan 95\% siswa 
mampu menangkap pesan pada media digital yang diberikan dibuktikan dengan siswa mampu memahami definisi bencana, jenis bencana dan cara mengantisipasi diri dan lingkungan terhadap bencana non alam covid 19 .

\section{HASIL DAN PEMBAHASAN}

Kegiatan pengabdian kepada masyarakat dimulai pada awal bulan Agustus 2020 diawali dengan kegiatan survey lokasi kegiatan. Pada kegiatan ini dilakukan wawancara dengan Kepala Sekolah dan guru kelas VI SDN 2 Kedungdawa untuk menentukan prioritas masalah yang ingin diselesaikan bersama dengan tim PKM UGJ. Dalam pertemuan ini ditemukan beberapa masalah antara lain, selama ini penggunaan media pembelajaran di dalam kelas belum dilakukan secara maksimal terutama pada materi bencana. Siswa hanya diberikan contoh melalui gambar, sehingga siswa sulit membayangkan bagaimana terjadinya bencana. Penggunaan media pembelajaran belum sesuai dengan karakteristik peserta didik. Siswa belum mampu memahami makna bencana dan belum sigap dan tanggap menghadapi situasi bencana serta belum memiliki tingkat empati yang tinggi terhadap korban bencana. Siswa sekolah dasar memiliki kecenderungan belajar dengan cara mengamati dengan seluruh panca indera sehingga akan dapat mudah memahami materi bencana alam dan non alam. Berkaitan dengan hal tersebut situasi saat ini tepat dijadikan sumber belajar peserta didik. Adanya pandemic covid 19 dapat dijadikan materi pembelajaran yang realistik untuk dapat dipahami oleh siswa. Lebih lanjut, virus covid 19 ini telah menyebar ke seluruh dunia, hampir semua negara terdampak akibat bencana non alam tersebut. Sehingga tema ini akan mudah dipahami oleh siswa melalui kegiatan multiliterasi.

Pelaksanaan kegiatan pendampingan dan penyuluhan mitigasi bencana melalui multiliterasi berlangsung pada hari Sabtu tanggal 29 Agustus 2020 pada pukul 08.00 sampai dengan 09.00 WIB. Pada kegiatan ini dilakukan penyuluhan secara daring melalui media social WhatsApp, siswa belajar dari rumah masing-masing, sedangkan tim pelaksana PKM bersama guru kelas berada di sekolah. Media social WhatsApp dipilih karena siswa telah mahir belajar daring melalui media tersebut. Adapun tahapan kegiatan dimulai dengan sesi penjelasan. Pada tahap ini disajikan sebuah video yang berisikan definisi bencana, macam-macam bencana serta mitigasi bencana. Dipilih bencana non alam covid 19 untuk dibahas lebih lanjut. Pemilihan ini berdasarkan karakteristik peserta didik bahwa siswa sekolah dasar akan lebih mudah memahami materi apabila materi yang disajikan realistik. Setelah siswa diberikan kesempatan untuk menonton video kemudian dilanjutkan dengan kegiatan sesi tanya jawab. Pada kegiatan ini siswa aktif bertanya mengenai materi. Setelah itu siswa diberikan angket respon mengenai pembelajaran melalui media pembelajaran video yang telah diamati sebelumnya. Sejumlah 24 siswa aktif mengisi angket respon tersebut. Selanjutnya pada penutup dibagikan sejumlah tanda mata untuk mengapresiasi peserta didik yang telah perpartisipasi aktif selama acara berlangsung. Hal ini sejalan dengan kegiatan yang dilakukan oleh Pahleviannur (2019).

Hasil kegiatan penyuluhan siswa mengenai mitigasi bencana, kemudian diukur dari respon siswa terhadap video pembelajaran yang telah disampaikan dan diamati oleh siswa sebelumnya. Angket respon menunjukkan bahwa sebagain besar siswa (85\%) siswa telah memahami definisi bencana, 95\% siswa telah mampu membedakan bencana alam dan non alam serta siswa ingin lebih menjaga kebersihan dari dengan lebih sering mencuci tangan dengan sabun, menggunakan masker bila berada di tempat umum, rajin berolahraga dan makan makanan bergizi untuk meningkatkan daya tahan tubuh. Sehingga capaian indikator membentuk siswa menjadi pembaca, penulis, dan komunikator yang strategis sehingga dapat memahami pesan yang disampaikan dalam kegiatan literasi digital telah tercapai. demikian dengan indicator meningkatkan kemampuan berpikir dan menanamkan kesigapan dan antisipasi terhadap bencana alam seta tanggap dan peduli terhadap korban bencana. 


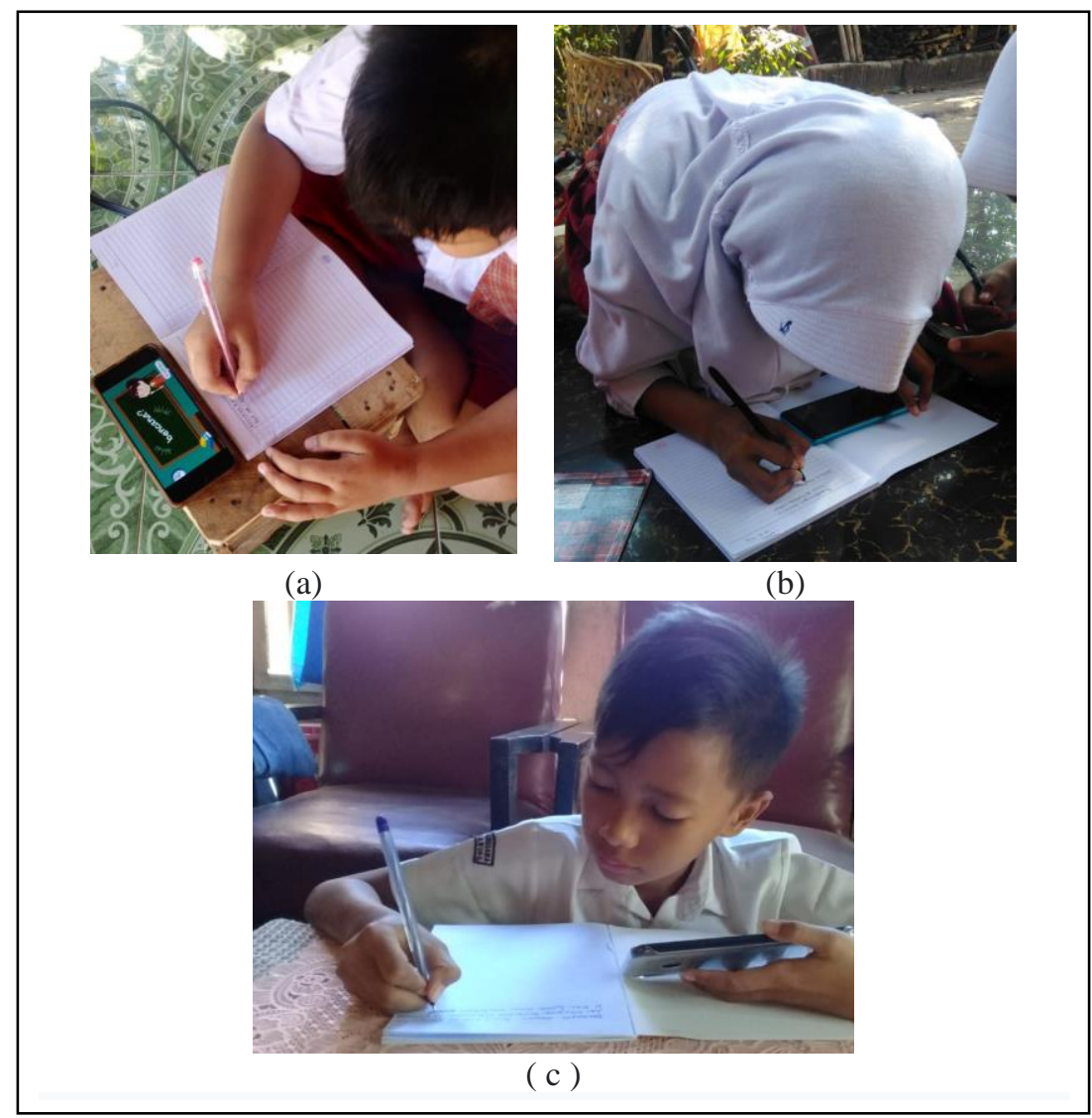

Gambar 1. Suasana kegiatan pelaksanaan kegiatan PKM

\section{Kutipan dan Acuan}

Acuan memuat nama pengarang yang pendapatnya dikutip, tahun sumber informasi ditulis, dan/tanpa nomor halaman tempat informasi yang dirujuk diambil. Nama pengarang yang digunakan dalam acuan hanya nama akhir. Acuan dapat dituliskan di tengah kalimat atau di akhir kalimat kutipan.

1. Acuan yang dituliskan di tengah kalimat dipisahkan dengan kata yang mendahului dan kata yang mengikutinya dengan jarak.

2. Acuan yang dituliskan diakhir kalimat dipisahkan dari kata terakhir kalimat kutipan dengan diberi jarak, namun tidak dipisahkan dengan titik.

3. Nama pengarang ditulis tanpa jarak setelah tanda kurung pembuka dan diikuti koma.

\section{KESIMPULAN}

Berdasarkan kegiatan pelaksanaan dan monitoring penyuluhan mitigasi bencana melalui kegiatan literasi yang dilaksanakan pada hari Sabtu tanggal 29 Agustus 2020 yang dihadiri oleh 24 siswa dan 7 orang guru serta 1 operator sekolah telah berjalan dengan lancar dan sukses. Diharapkan kegiatan ini mampu meningkatkan pengetahuan dan pemahaman peserta didik mengenai bencana, macam bencana serta mitigasi bencana. Peserta didik semakin tanggap bencana dan memiliki kepedulian yang tinggi terhadap korban bencana. 


\section{UCAPAN TERIMAKASIH}

Terimakasih sebesar-besarnya kepada Lembaga Pengabdian Masyarakat Universitas Swadaya Gunung Jati yang telah mendanai kegiatan penyuluhan ini, sehingga seluruh rangkaian kegiatan dapat berlangsung dengan baik dan lancar tanpa kendala yang berarti

\section{DAFTAR PUSTAKA}

Abidin, Y. 2015. Pembelajaran Multiliterasi. Bandung : Refika Aditama.

Cumming-potvin,W. "Multiliteracies and On-Line Discussions in a Community of Practice," vol. 17, no. 1, pp. 21-41, 2015

Cumming-Potvin, W and Currie, J.2013. "Towards New Literacies and Social Justice for Engineering Education," Int. J. Eng. Soc. Justice, Peace, vol. 2, no. 1, pp. 21-37, doi: 10.24908/ijesjp.v2i1.3516.

Hardoyo, SR. 2011. Strategi Adaptasi Masyarakat Dalam Menghadapi Bencana Banjir Pasang Air Laut di Kota Pekalongan.Yogyakarta : Fakultas Geografi Universitas Gajah Mada

Herdwiyanti, F. Sudaryono. 2013. Perbedaan Kesiapsiagaan Menghadapi Bnecana Ditinjuau dari Tingkat Self Efficacy pada Anak Usia Sekolah Dasar di Daerah Dampak Bencana Gunung Kelud. Jurnal Psikologi Kepribadian dan Sosial 2(1): 136-141.

Honesti, L. Nazwar, D. 2012. Pendidikan Kebencanaan di Sekolah di Indonesia Berdasarkan Beberapa Sudut Pandang Disiplin Ilmu Pengetahuan. Jurnal Momentum 2(1) : 51-55.

Lesmana, C. Purobrini, N. 2015. Kesiapsiagaan Komunitas Sekolah dalam Menghadapi Bencana di Kabupaten Magelang. Jurnal Tek Sipil 11(1): 1-7.

Pahleviannur, R.M. 2019. Edukasi Sadar Bencana Melalui Sosialisasi Kebencanaan sebagai Upaya Peningkatan Pengetahuan Siswa terhadap Mitigasi Bencana. Jurnal Pendidikan dan Ilmu Sosial 29(1): 49-55.

Pyo. J,2016. "Bridging In- -," vol. 59, no. February, pp. 421-430. doi: 10.1002/jaal.467.

Ryan,G.T. 2020. "Multiliteracies and multiple literacies within ontario (Canada) health and physical education," Int. J. Res. Educ. Sci., vol. 6, no. 4, pp. 568-579, doi: 10.46328/ijres.v6i4.1225.

Setyorini. 2020. Terhadap Proses Pembelajaran Pada Kurukulum 13 ? Jiemar, 1(Juni), 95-102.

Sunarto, N. 2012. Edukasi Penanggulangan Bencana Lewat Sekolah. Diakses di http://bpbd.banjarkab.go.id/?p-75/

Zein,MA. 2010. Community Based Approach to Flood Hazard and Vulnerability Assessment in Flood Prone Area: A Case Study in Kelurahan Sewu, Surakarta City, Indonesia. Thesis, ITC, The Netherland. 